\title{
Clinico-bacteriological study of diabetic foot ulcer and its management based on Wagner's classification and HbA1c as an indicator for duration of antibiotic therapy in a tertiary hospital in Sullia
}

\author{
Abhirup H. R., Chidananda K. V., Jagadish B., Ranjith K. B.*, \\ Gopinath Pai, Balakrishna M. A.
}

Department of General Surgery, KVG Medical College and Hospital, Sullia, Karnataka, India

\author{
Received: 27 April 2021 \\ Revised: 28 May 2021 \\ Accepted: 29 May 2021 \\ *Correspondence: \\ Dr. Ranjith K. B., \\ E-mail: ranjithkurunji@gmail.com
}

Copyright: () the author(s), publisher and licensee Medip Academy. This is an open-access article distributed under the terms of the Creative Commons Attribution Non-Commercial License, which permits unrestricted non-commercial use, distribution, and reproduction in any medium, provided the original work is properly cited.

\begin{abstract}
Background: Diabetic foot ulcer is a serious and common complication of diabetes mellitus. $12 \%-25 \%$ have a risk of developing a foot ulcer during their lifetime. Diabetic neuropathy and micro- or macro-ischemia are the two main risk factors that cause diabetic foot ulcer.

Methods: A cross sectional study was conducted in dept of general surgery, KVGMCH between $1^{\text {st }}$ November 2019 and $30^{\text {th }}$ August 2020 among 90 pts with diabetic foot ulcers, selected by systematic random sampling methods. Considering prevalence of DFU, among the diabetic pts as $8.8 \%$, the sample size was estimated to be 90 using the formula $4 \mathrm{pq} / \mathrm{L}^{2}$, with absolute error as $6 \%$. Patients will be managed conservatively with antibiotics like aminoglycosides, cephalosporins, penicillin derivatives and dressings and if needed surgical interventions will be performed.

Results: Maximum number of pts had HbA1c levels of $>8 \%$ and they accounted for 35.55\%. Almost $98 \%$ of the patients had neuropathy, $50 \%$ of them had signs of ischemia and $80 \%$ had infection. Maximum number of patients $(58.88 \%)$ presented with diabetic ulcers belonging to Class 2 of Wagners classification. The most commonly isolated $P$. aeruginosa was sensitive to colistin, imipenem and amikacin. Most diabetics with HbA1C levels $>8$, had mean antibiotic duration of $19.04 \pm 4.65$ days.

Conclusions: Prevention is the best treatment. Wagner's classification helps in correlating appropriate treatment to proper grade of lesion with better outcome. Effective glycemic control and education are of key importance for decreasing diabetic foot disease.
\end{abstract}

Keywords: Diabetic foot, HbA1C, Wagner's

\section{INTRODUCTION}

Diabetic foot is defined the foot of a diabetic patient that has the potential risk of pathologic consequences, including infection, ulceration, and/or destruction of deep tissues associated with neurological abnormalities, various degrees of peripheral vascular disease, and/or metabolic complications of diabetes in the lower limb. ${ }^{1}$
Approximately 425 million adults (20-79 years age range) are living with diabetes, by 2045 this will rise to 629 million. In India, there are over 72.9 million cases of diabetes in 2017. Prevalence of diabetes in adults in India is $8.8 \% .^{2}$

Diabetic foot ulcer is a serious and common complication of diabetes mellitus. $12 \%-25 \%$ have a risk of developing 
a foot ulcer during their lifetime. The most common cause of morbidity and mortality in diabetic foot ulcer is infections, which are seen in $40 \%-80 \%$ of the cases. Diabetic neuropathy and micro- or macro-ischemia are the two main risk factors that cause diabetic foot ulcer. These types of situations necessitate limb amputation. Thus, accurate diagnosis of the causative organism is essential for the management of these cases. Mostly, the diabetic foot infections are mixed bacterial infections, and the proper management of these infections requires an appropriate antibiotic selection, based on the culture and the antimicrobial susceptibility testing results. Hence, the present study was conducted to determine clinical profile of the patients, to diabetic foot ulcers according to Wagner's classification and their appropriate management with their bacteriological profile of organisms and antibiotic susceptibility patterns. This study also aims at determining relationship between $\mathrm{HbA} 1 \mathrm{C}$ and duration of antibiotic therapy in patients with diabetic foot ulcers.

\section{METHODS}

A cross sectional study was conducted in Dept of general surgery, KVGMCH between $1^{\text {st }}$ November 2019 and $30^{\text {th }}$ August 2020, among 90 pts with diabetic foot ulcers, selected by systematic random sampling methods. The Institutional Ethical Committee's clearance was obtained prior to conducting the study. Considering prevalence of DFU, among the diabetic pts as $8.8 \%$, the sample size was estimated to be 90 using the formula $4 \mathrm{pq} / \mathrm{L}^{2}$, with absolute error as $6 \%$. Detailed history will be elicited by pre-prepared case file, clinical examination, investigations, and relevant special investigations. The wound swab of the patient will be sent to department of microbiology for bacteriological study, the isolates if detected, will be subjected to standard methods for identification and antibiotic sensitivity testing. ${ }^{5}$ Patients will be managed conservatively with antibiotics like aminoglycosides, cephalosporins, penicillin derivatives and dressings and if needed surgical interventions will be performed. Statistical analysis will be made using descriptive statistic and SPSS version 21 was used for analysis.

\section{Wagner's classification for diabetic foot disease. ${ }^{4}$}

Grade 0 - High risk foot and no ulceration,

Grade 1- Superficial Ulcer; Total destruction of the thickness of the skin,

Grade 2- Deep Ulcer (cellulitis); Penetrates through skin, fat, ligaments not affecting bone,

Grade 3- Osteomyelitis with Ulceration or abscess,

Grade 4- Gangrenous patches limited to toes or part of the foot,

Grade 5- Gangrene of the entire foot.

\section{Inclusion criteria}

- The patients with Type 1 and 2 Diabetes Mellitus with foot ulcer admitted to KVG Medical College Hospital, Sullia during the period of study.

\section{Exclusion criteria}

- Patients with foot ulcers other than diabetes.

- Pregnant and Lactating women.

\section{RESULTS}

Maximum number of pts had HbA1c levels of $>8 \%$ and they accounted for $35.55 \%$.

Table 1: Comparison of HbA1c levels.

\begin{tabular}{|lll|}
\hline Glycated Haemoglobin & \\
\hline $\mathbf{4 - 5 . 6 \%}$ & 0 & $0 \%$ \\
\hline $\mathbf{5 . 7 - 6 . 4 \%}$ & 8 & $8.8 \%$ \\
\hline $\mathbf{6 . 5 - 8 \%}$ & 32 & $35.55 \%$ \\
\hline $\mathbf{> 8 \%}$ & 50 & $55.55 \%$ \\
\hline
\end{tabular}

Table 2: Location of the ulcer.

\begin{tabular}{|lll|}
\hline Site of wound & No. of patients & Percentage $(\%)$ \\
\hline Great Toe & 21 & 23.33 \\
\hline $\begin{array}{l}\text { Metarsal head of } \\
\text { other Toes }\end{array}$ & 23 & 25.55 \\
\hline Fore Foot & 19 & 21.11 \\
\hline Heel & 18 & 20 \\
\hline Medial Malleoli & 7 & 7.77 \\
\hline Lower 1/3 & of LL & 2 \\
\hline
\end{tabular}

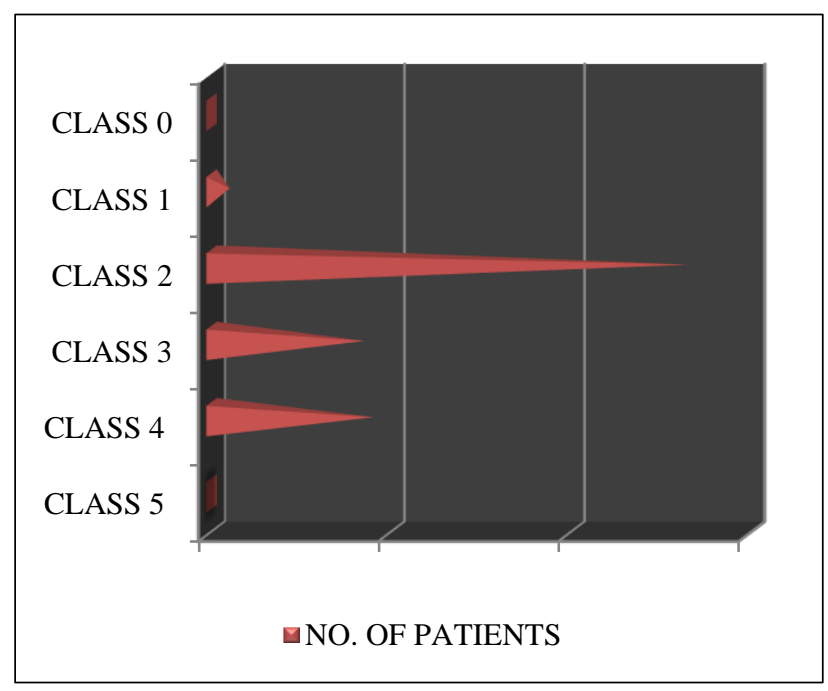

Figure 1: Distribution of patients based on Wagners classification.

Maximum number of patients $(25.55 \%)$ presented with diabetic ulcers over the metatarsal head of toes, followed by great toe $(23.33 \%)$. 
Maximum number of patients $(58.88 \%)$ presented with diabetic ulcers belonging to Class 2 of Wagners classification followed by $20 \%$.
Most patients (11.11\%), in arterial doppler had both anterior and posterior tibial artery involved equally.

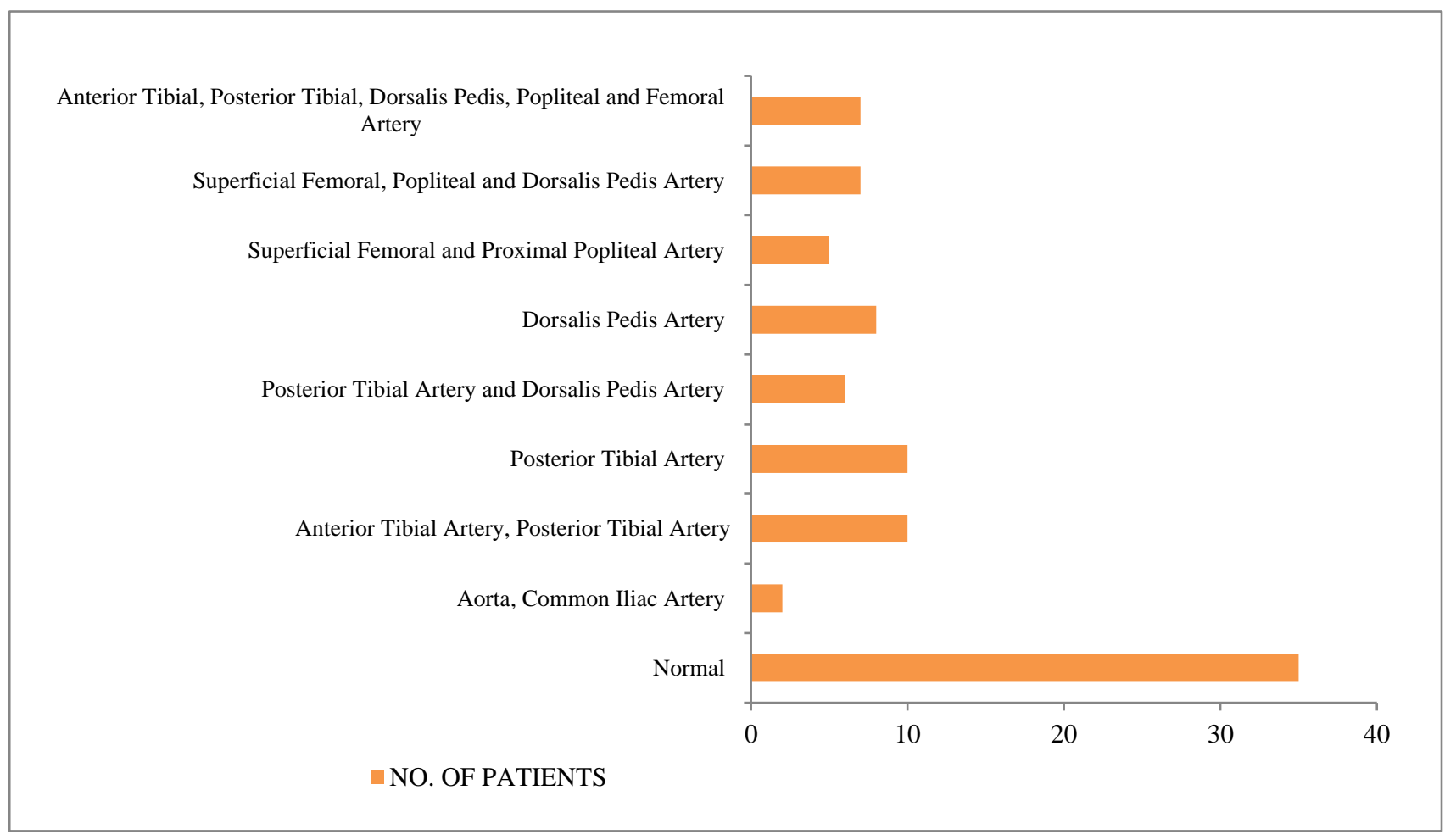

Figure 2: Level of peripheral artery disease.

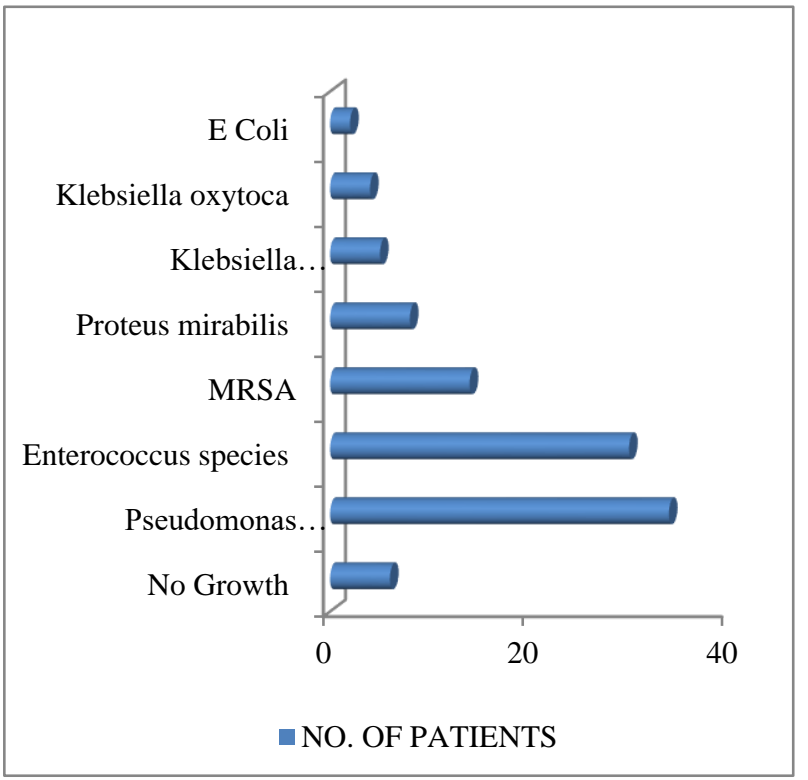

Figure 3: Organisms isolated from culture of diabetic foot.

Pus C/S showed predominance of Pseudomonas aeroginosa $(37.77 \%)$ in pts with DFU.

The duration of hospital stay and antibiotic therapy was 11-20 days (62.22\%) in pts with DFU. Average duration being $16.88 \pm 5.32$.
The most commonly isolated $P$. aeruginos $a$ was sensitive to colistin, imipenem and amikacin. Second most commonly isolated Enterococcus spp. was sensitive to gentamicin and ampicillin.

The most commonly isolated $P$. aeruginosa was resistant to cefaperazone/sulbactam, ceftriaxone and cefotaxime. Second most commonly isolated Enterococcus spp. was resistant to cotrimaxazole, erythromycin and azithromycin.

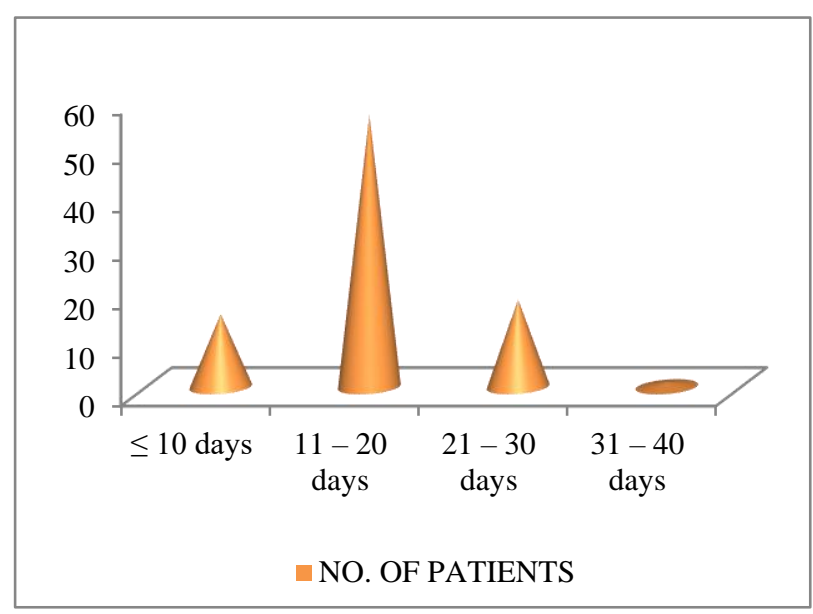

Figure 4: Duration of hospital stay. 


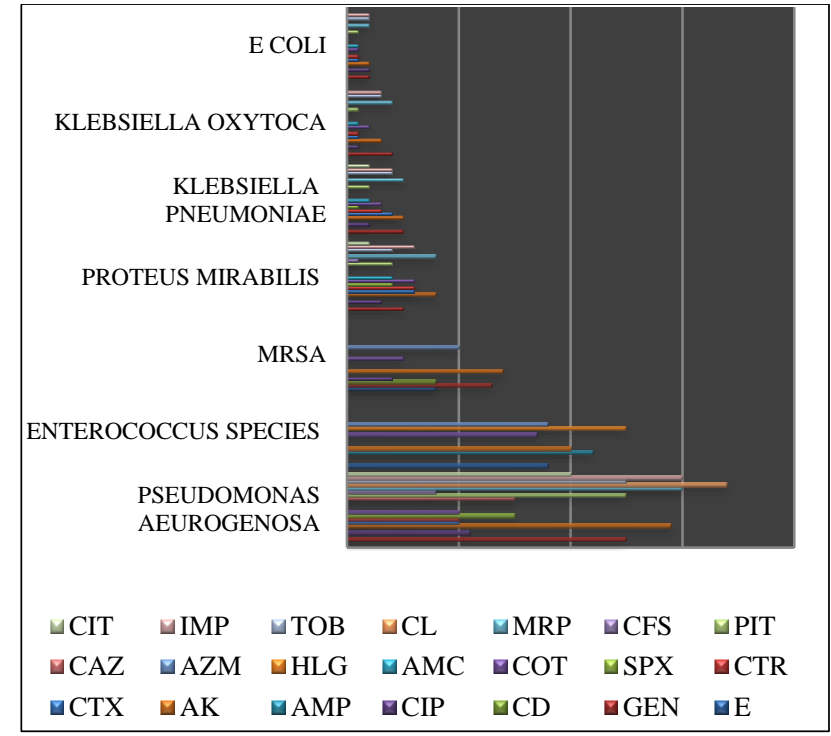

Figure 5: Sensitivity pattern of organisms isolated.

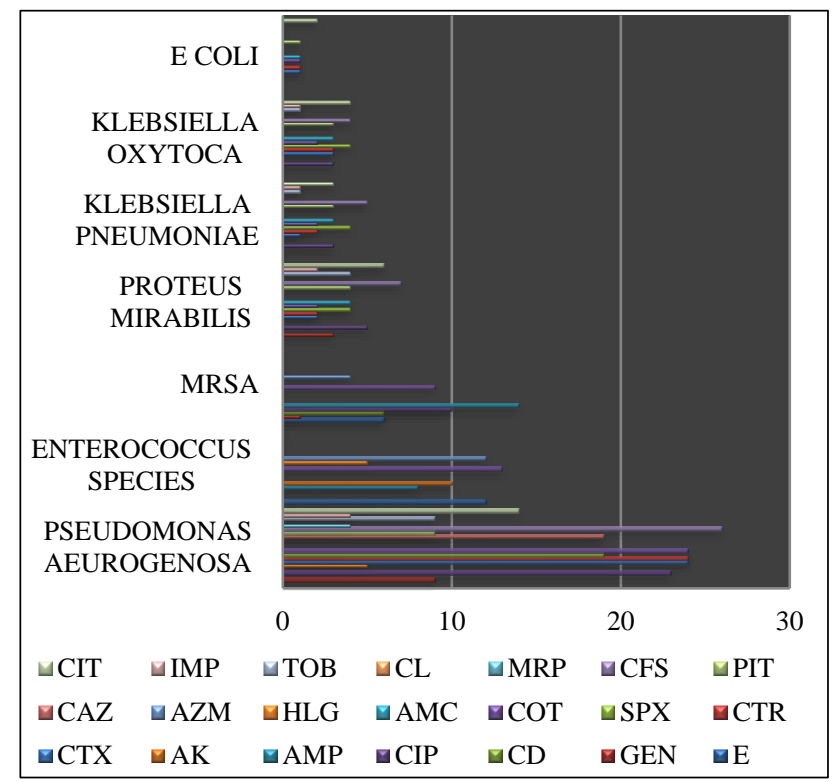

Figure 6: Resistance pattern of organisms isolated.

Table 3: Final management of Diabetic foot ulcer.

\begin{tabular}{|c|c|c|c|c|c|c|}
\hline Treatment & Clas & $\begin{array}{l}\text { Class } \\
1\end{array}$ & $\begin{array}{l}\text { Class } \\
2\end{array}$ & $\begin{array}{l}\text { Class } \\
\mathbf{3}\end{array}$ & $\begin{array}{l}\text { Class } \\
4\end{array}$ & $\begin{array}{l}\text { Class } \\
5\end{array}$ \\
\hline Conservative & - & 2 & - & - & - & - \\
\hline $\begin{array}{l}\text { Debridement } \\
\text { only }\end{array}$ & - & - & 53 & 10 & - & - \\
\hline $\begin{array}{l}\text { Debridement a } \\
\text { disarticulation }\end{array}$ & - & - & - & 7 & - & - \\
\hline $\begin{array}{l}\text { Fore Foot } \\
\text { amputation }\end{array}$ & - & - & - & - & 16 & - \\
\hline $\begin{array}{l}\text { Below Knee } \\
\text { amputation }\end{array}$ & - & - & - & - & 1 & - \\
\hline $\begin{array}{l}\text { Above Knee } \\
\text { amputation }\end{array}$ & - & - & - & - & 1 & - \\
\hline
\end{tabular}

Table 4: Mean duration of antibiotic therapy according to HbA1C levels.

\begin{tabular}{|llll|}
\hline $\begin{array}{l}\text { HbA1c } \\
\text { levels }\end{array}$ & $\begin{array}{l}\text { Mean duration } \\
\text { of antibiotics }\end{array}$ & F value & P value \\
\hline $\mathbf{5 . 7}$ to $\mathbf{6 . 4 \%}$ & $10.75 \pm 2.31$ & & \\
\cline { 1 - 2 } $\mathbf{6 . 5}$ to $8 \%$ & $16 \pm 5.10$ & & \\
\hline $\mathbf{> 8 \%}$ & $19.04 \pm 4.65$ & & $<0.0001 *$ \\
\hline
\end{tabular}

Tukey HSD Post-hoc Test.

Group 1 vs Group 2: Diff $=5.2500,95 \% \mathrm{CI}=0.8416$ to 9.6584 , $\mathrm{p}=0.0154^{*}$

Group 1 vs Group 3: Diff $=8.2900,95 \% \mathrm{CI}=4.0433$ to 12.5367 , $\mathrm{p}=0.0000 *$

Group 2 vs Group 3: Diff $=3.0400,95 \% \mathrm{CI}=0.5152$ to 5.5648 , $\mathrm{p}=0.0141^{*}$

\section{DISCUSSION}

Diabetic foot ulcers are one of the most difficult and threatening complications which a diabetic patient faces during the period of uncontrolled glycemic control along with other complications. In the present study Wagners classification has been used to grade the foot ulcers due to diabetes.

In the present study, the proportion of males suffering from DFS were more compared to females $(83.3 \%$ Vs $16.7 \%)$. These findings were similar to that of studies done by Jeffcoate EJ et al (67\%) and Shailesh Shahi et al $(71.13 \%)$ were they found that the proportion was higher in males when compared to females. ${ }^{5,6}$ Study conducted by Tjokorda et al shows that there is equal proportion of males and females affected. ${ }^{7}$ The reason for males being more commonly affected may be because they are more exposed to hard work with higher risk of trauma in their work place.

The average age of the study population was 56.48. This was similar to another study done by Dalem Pemayun TG et al were the mean age was $54.3 \pm 8.6$ years. ${ }^{8}$ There is more chance of elderly people to have long standing diabetes, peripheral neuropathy, gait abnormalities, and poor vision which makes them more susceptible for ulcers.

In the present study, $97.7 \%$ of the patients had neuropathy, 50\% had ischemia and $80 \%$ were infected. Nyamu PN et al studied 1780 diabetic patients and found that $47.5 \%$ of the ulcers were neuropathic, $30.5 \%$ were neuroischemic and $18 \%$ were ischemic. ${ }^{9}$ Lack of proper blood sugar control, hypertension, lack of proper self care and infections are considered as significant risk factors for the development of ulcers.

Zhang $\mathrm{P}$ et al, carried out a systematic review and meta analysis and found that increasing age, more duration of diabetes and smoking were associated with the diabetic foot ulcer. ${ }^{10}$ Almost $90 \%$ of our study population had HbA1c levels more than 6.5 and $34 \%$ of them had some associated comorbidities. 
In the present study, it was found that P. Aeroginosa $(37.77 \%)$ was the most common organism isolated, followed by Enterococcus species (33.33\%). Some studies show that $\mathrm{S}$. aureus was the most frequent pathogen, followed by E. coli. ${ }^{11-13}$ In contrast, another study carried out by Ako-Naiet al showed E. coli as the frequent bacterial pathogen, while $P$. aeruginosa was reported as the most common pathogen by Shankar et al and Jayashree Konar. ${ }^{14-16}$

Pseudomonas was sensitive to imipenem, amikacin and gentamicin. Commonly used antibiotics like ceftrizxone and ciprofloxacin were resistant. Biofilms, present in chronic wounds, are a defensive mechanism for bacteria against the effects of antibiotics and can explain the rise in AMR. ${ }^{17,18}$ Unjustified use of antibiotics is another cause of AMR, misuse of health resources and a burden to patients and their families. ${ }^{19-21}$ From this present study, amikacin is effective against most Gram-negative bacteria. The high AMR to ampicillin should warrant care during empirical treatment of DFUs in this setting. ${ }^{22}$

An ulcer is the most common presentation of diabetic foot, whereas plantar callus is a risk factor for ulceration. $^{23,24}$ The great toe is the most common site of callus formation. ${ }^{23}$ In our study, metatarsal heads were the most common site of foot ulcer followed by the great toe. Some patients had ulcers on the gaiters area. In another study, $44 \%$ foot ulcers were found on the toes and $43 \%$ on the plantar surface. ${ }^{25}$

Previous studies have shown that a $1 \%$ decrease in HbA1c results in a $21 \%$ reduction in all diabetic complications. ${ }^{26,27}$ However, this correlation is affected by many external factors and its relation to the duration of antibiotic therapy is not clearly defined. For this reason, it is important to examine the relationship between $\mathrm{HbA} 1 \mathrm{C}$ levels and duration of antibiotic therapy which is an important indicator of diabetes regulation. ${ }^{24-29}$ When the results of the present study was examined, it was seen that the duration of treatment was prolonged in the patient group who had $\mathrm{HbA} 1 \mathrm{C}$ value above $7 \%$ and this was found to be statistically significant also. The level of $\mathrm{HbA} 1 \mathrm{C} 7 \%$ is recommended to deal with other complications of diabetes, mainly cardiovascular disease risk. ${ }^{30}$ When patients were grouped according to $\mathrm{HbA} 1 \mathrm{C}$ levels, patients with higher HbA1C levels (excluding $>15 \%$ group) had a longer treatment duration.

The main limitations of our study were that of patients were limited to the patients admitted to our hospital. Specifically, the association of HbA1C levels with the duration of antibiotic use may provide inspiring ideas for large-scale prospective studies concerning antibiotic use and duration of hospitalisation, of patients with diabetic foot ulcers.

\section{CONCLUSION}

Foot ulceration in diabetic patients is resource consuming, disabling morbidity that often is the first step towards lower extremity amputation. This study showed that most common organism present in Diabetic foot ulcer was $P$. aeroginosa. These observations from our study are important, especially for patient management and development of empirical antibiotic guidelines. The prolongation of antibiotic therapy has been associated with elevated $\mathrm{HbA} 1 \mathrm{C}$ levels and poor prognosis in many studies in literature. Wagner's classification helps in correlating appropriate treatment to proper grade of lesion with better outcome. Lesser grade lesion respond well to conservative treatment with antibiotics and debridement, while those with higher lesion require some kind of amputation. Keeping the HbA1C level $<7 \%$ in the development of diabetic foot wounds is important for the prevention of diabetic foot and other major complications. Treatment of diabetic foot infections with a multidisciplinary approach can be accomplished, and morbidity can be reduced. ${ }^{31}$ Thus from our study, we can ascertain that timely and most effective approach to diabetic foot wound infections can reduce morbidity, shorten treatment time and prevent other complications of diabetes.

\section{Funding: Biocell Pharmaceuticals Pvt Ltd, Chandigarh Conflict of interest: None declared}

Ethical approval: The study was approved by the Institutional Ethics Committee of KVG Medical College and Hospital, Sullia, Karnataka, India

\section{REFERENCES}

1. Frier M, Fischer M. Diabetes Mellitus. Davidsons principles practice of medicine. Churchill Livingstone, Elsevier; 20th Ed. 2009:810.

2. International Diabetes Federation.Idf.org.2019. Available at: https://www.idf.org/aboutdiabetes/ what-is-diabetes/facts-figures.html. Accessed 15 Oct. 2019.

3. Jain SK, Barman R. Bacteriological profile of diabetic foot ulcer with special reference to drugresistant strains in a tertiary care center in NorthEast India. Indian J Endocr Metab. 2017;21:688-94.

4. Andrew JM, Bpoulton, Vileikyte L. Diabetic foot problems and their management around the world. Levin o neal "the diabetic foot". 6th ed. mosby, inc; 2001:266.

5. Jeffcoate WJ, Harding KG. Diabetic foot ulcers. Lancet. 2003;361:1545-51.

6. Shahi S, Kumar A, Kumar S, Singh S, Gupta S, Singh T B. Prevalence of Diabetic Foot Ulcer and Associated Risk Factors in Diabetic Patients From North India. J Diab Foot Complic 2012;4(3):83-91.

7. Dalem Pemayun T, Naibaho RM. Diabetic Foot Ulcer Registry at a Tertiary Care Hospital in Semarang, Indonesia: an Overview of its Clinical 
Profile and Management Outcome. Diab Manag. 2016;6(4):82-9.

8. Pemayun TG, Naibaho RM. Clinical profile and outcome of diabetic foot ulcer, a view from tertiary care hospital in Semarang, Indonesia. Diab Foot Ankle. 2017;8(1):1312974.

9. Nyamu PN, Otieno CF, Amayo EO, McLigeyo SO. Risk factors and prevalence of diabetic foot ulcers at Kenyatta National Hospital, Nairobi. East African Med J. 2003;80(1):36-43.

10. Zhang P, Lu J, Jing Y, Tang S, Zhu D, Bi Y. Global epidemiology of diabetic foot ulceration: a systematic review and meta-analysis. Ann Med. 2017;49(2):106-16.

11. Abdulrazak A, Bitar ZI, Al Shamali AA, Mobasher LA. Bacteriological study of diabetic foot infections. J Diab Complic. 2005;19:138 41.

12. El Tahawy AT. Bacteriology of diabetic foot. Saudi Med J. 2000;21:344 7.

13. Amini M, Davati A, Piri M. Determination of the resistance pattern of prevalent aerobic bacterial infections of diabetic foot ulcer. Iran J Pathol. 2013;8:216.

14. Ako Nai A, Ikem I, Akinloye O, Aboderin A, Ikem $\mathrm{R}$, Kassim O. Characterization of bacterial isolates from diabetic foot infections in Ile Ife, Southwestern Nigeria. Foot (Edinb). 2006;16:158.

15. Shankar EM, Mohan V, Premalatha G, Srinivasan RS, Usha AR.Bacterial etiology of diabetic foot infections in South India. Eur J Intern Med. 2005; $16: 567$.

16. Konar J, Das S. Bacteriological profile of diabetic foot ulcers, with special reference to antibiogram in a tertiary care hospital in Eastern India. J Evol Med Dent Sci. 2013;2(48):9323-8.

17. Spichler A, Hurwitz BL, Armstrong DG, Lipsky BA. Microbiology of diabetic foot infections: from Louis Pasteur to "crime scene investigation". BMC Med. 2015;13:2.

18. Banu A, Noorul Hassan MM, Rajkumar J, Srinivasa S. Spectrum of bacteria associated with diabetic foot ulcer and biofilm formation: a prospective study. Aust Med J. 2015;8(9):280-5.

19. Uckay I, Gariani I, Pataky Z, Lipsky BA. Diabetic foot infections: state-of-the-art. Diabetes Obes Metab. 2014;16(4):305-16.

20. Reiber GE, Pecoraro RE, Koepsell TD. Risk factors for amputation in patients with diabetes mellitus. A case-control study. Ann Intern Med. 1992;117:97-105.

21. Karugu L. Mainstreaming diabetic foot education in Kenya: prevalence of diabetes in Kenya. In: World, I. D. F., \& Congress D, editor. 2011.

22. Achieng L, Menge TOE. The KNH guide to empiric antibiotic therapy. 2nd ed. Nairobi: Kenyatta National Hospital; 2018.

23. Unnikrishnan AG: Approach to a patient with a diabetic foot. Natl Med J India. 2008;21:134-7.

24. Murray HJ, Young MJ, Hollis S, Boulton AJ: The association between callus formation, high pressures and neuropathy in diabetic foot ulceration. Diabet Med. 1996;13:979-82.

25. Tantisiriwat N, Janchai S. Common foot problems in diabetic foot clinic. $\mathbf{J}$ Med Assoc Thai. 2008;91:1097-101.

26. Lepore G, Maglio ML, Cuni C, Dodesini AR, Nosari I, Minetti B, et al. Poor glucose control in the year before admission as a powerful predictor of amputation in hospitalized patients with diabetic foot ulceration. Diabetes Care. 2006;29:1985.

27. Slovenkai MP. Foot problems in diabetes. Med Clin North Am. 1998;82:949-71.

28. Bennett PJ, Stocks AE, Whittam DJ. Analysis of risk factors for neuropathic foot ulceration in diabetes mellitus. J Am Podiatr Med Assoc. 1996;86:112-6.

29. Ertugrul BM, Lipsky BA, Guvenc U. Turkish Intralesional Epidermal Growth Factor Study Group for Diabetic Foot Wounds. An assessment of intralesional epidermal growth factor for treating diabetic foot wounds the first experiences in Turkey. J Am Podiatr Med Assoc. 2017;107:17-29.

30. Lipsky BA, Berendt AR, Cornia PB, Pile JC, Peters EJ, Armstrong DG, et al. 2012 Infectious Diseases Society of America Clinical Practice Guideline for the Diagnosis and Treatment of Diabetic Foot Infections. IDSA Guideline CID; 2012:54.

31. Eren Z. Davutoğlu M, Ulay M, Özsoy Z, Olcay E. Bayca 1. Diabetik ayak infeksiyonları. Türk Diyabet Yıllığ1. 1998-99;323-7.

Cite this article as: Abhirup HR, Chidananda KV, Jagadish B, Ranjith KB, Pai G, Balakrishna MA. Clinico-bacteriological study of diabetic foot ulcer and its management based on Wagner's classification and $\mathrm{HbA} 1 \mathrm{c}$ as an indicator for duration of antibiotic therapy in a tertiary hospital in Sullia. Int Surg J 2021;8:2098-103. 